\title{
PENDIDIKAN ISLAM MULTIKULTURALISME
}

\section{Saihu}

STIT Al-Amin Kreo Tangerang

made_syaikhu@yahoo.com

\begin{abstract}
:
A simple definition of education is how to improve the potential of human life adapted with our values and cultures. While multiculturalism many experts define a diverse or compound. Indonesia has got more than 300 tribes actually they have different cultures, values, languages etc that sometimes happening a conflict. in this way Islamic Multiculturalism Education expected can solve the problems in our state or communities, at least give some awareness that conflict is not good situation to developed. Education has to capable give the bids which a smart solution, such as designing material, method and curriculum that make the communities understood the importance of tolerance, honor each other, can live together with different background.
\end{abstract}

Keywords: Islamic Education, Multiculturalism, Values. 


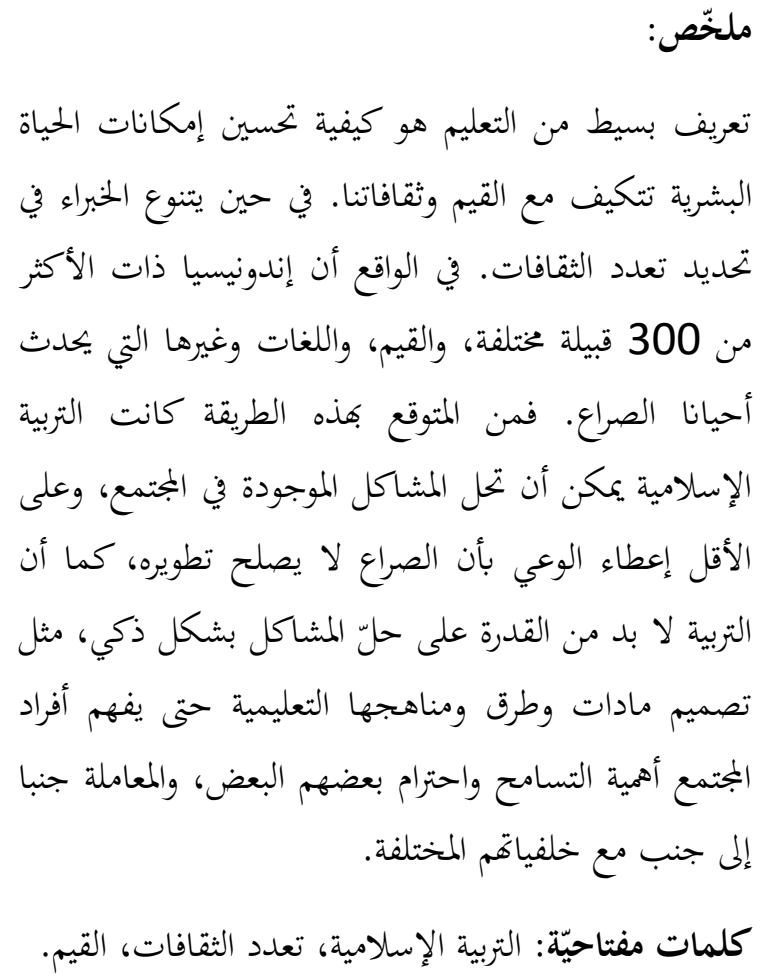

$\mathrm{K}$

emajemukan dan keragaman masyarakat di dunia ini adalah sebuah realitas peradaban yang nyata adanya dengan ditandai dengan berbagai keragaman seperti: jenis kelamin, ras, etnis, agama, budaya dan sebagainya. Begitupun yang terjadi di Indonesia, yang notabene dikenal sebagai negara multikultural, yang memiliki semboyan Bhineka Tunggal Ika. Betapa tidak, secara geografis wilayah Indonesia yang terbentang dari Sabang sampai Merauke, terdiri dari ribuan pulau yang masing-masing didiami oleh penduduk dengan latar belakang budaya, etnis, suku, agama yang berbeda-beda. Maka tidak heran akhirnya dalam peristiwa Sumpah Pemuda 28 Oktober 1928 menjadi suatu penanda bahwa memang masyarakat Indonesia adalah masyarakat multikultural. Sumpah Pemuda 28 Oktober 1928 mempersatukan berbagai organisasi pemuda dari daerah-daerah yang berbeda-beda di Indonesia, seperti Jong 
Java, Jong Soematranen Bond, Jong Bataks Bond, Jong Islamieten Bond, Pemoeda Indonesia, Jong Celebes, Jong Ambon, Pemoeda Kaoem Betawi, perwakilan kaum Tionghoa dan Arab dan lain sebagainya. Dalam peristiwa tersebut, mereka bekerja keras untuk dapat merumuskan suatu rumusan yang dapat mengintegrasikan mereka dengan perbedaan latar belakang, yaitu dengan terciptanya pernyataan kedaulatan sebagai satu bangsa, satu tanah air, dan menjunjung bahasa persatuan bahasa Indonesia. ${ }^{1}$

Berkaca pada problematika keberagaman yang ada di Indonesia perlu adanya penelitian terhadap konsep pendidikan multikultural, karena konsep tersebut belum dikenal oleh pakar pendidikan Islam saat ini. Boleh jadi konsep tersebut sudah ada sejak zaman Nabi Muhammad Saw yang diutus menjadi Rasul melalui Piagam Madinah yang terkenal itu. Azyumardi Azra, ${ }^{2}$ menjelaskan bahwa Pendidikan Multikultural berawal dari perkembangannya gagasan dan kesadaran tentang interkulturalisme setelah Perang Dunia.

Tujuan pendidikan multikultural inilah yang diharapkan dapat mengubah tingkah laku individu agar tidak meremehkan apalagi melecehkan budaya orang lain atau kelompok lain khususnya dari kalangan minoritas. Menurut Herry Sucipto, ${ }^{3}$ ada empat tujuan yang berkaitan dengan pendidikan multikultural yaitu: (1) mengembangkan perspektif sejarah (etnohistorisitas) yang beragam dari masyarakat; (2) memperkuat kesadaran budaya yang hidup dalam masyarakat; (3) memperkuat kompetensi interkultural dari budaya-budaya yang hidup dalam masyarakat; (4) membasmi rasisme dan berbagai jenis prasangka; (5) mengembangkan kesadaran atas kepemilikan planet bumi; dan (6) mengembangkan keterampilan aksi sosial. Selain itu, pendidikan multikultural ditujukan untuk menumbuhkan toleransi dalam diri individu terhadap berbagai perbedaan rasial, etnis, agama, dan lain-lain. Konsep pendidikan

http://www.kompasiana.com/satriwan/pendidikankarakter-dalam-bingkai-multikulturalisme.

2 Azyurmadi Azra, Pendidikan Islam, Tradisi dan Modernisasi Menuju Milenium Baru, (Jakarta: Logos 1990), h. 34.

3 Herry Sucipto, Lili Hermawan, Pendidikan Multikultural untuk Kemajuan Bangsa, dalam Nadjamuddin Ramly, Membangun Pendidikan Yang Memberdayakan dan Mencerahkan, (Jakarta: Grafindo, 2005), h. 26.

172| Al Amin:Jurnal Kajian Ilmu dan Budaya Islam, Volume 1, No 2, 2018 
multikultural melihat masyarakat secara lebih luas, berbeda dengan konsep pendidikan interkultural.

Konsep dasar pendidikan multikultural perlu ditelusuri dalam sejarah pendidikan Islam. Upaya menelusurinya dimulai pada zaman al-Ma'mun dengan pertimbangan bahwa pada zaman itu Islam mengalami masa kejayaan dan alMa'mun terkenal sebagai tokoh intelektual yang gigih dalam mengembangkan ilmu pengetahuan dan mengelola lembaga pendidikan Bait al-Hikmah.

\section{A. Pengertian Pendidikan Multikultural}

Pendidikan multikultural berasal dari kata 'kebudayaan', dalam bahasa Belanda yang disebut cultur, dalam bahasa Inggris disebut culture. Sedangkan dalam bahasa Arab disebut tsaqāfah, selain itu dalam pengertiannya yang berasal dari perkataan Latin, artinya mengolah mengerjakan, menyuburkan dan mengembangkan terutama mengolah tanah atau bertani. Dari arti ini berkembanglah arti culture sebagai "segala daya dan aktivitas manusia untuk mengolah dan mengubah alam". 4

Multikulturalisme adalah sebuah ideologi yang menekankan kederajatan dalam perbedaan kebudayaankebudayaan. 5 Dari dasar pengertian ini dapat dikatakan bahwa pendidikan multikultural adalah pendidikan yang menekankan kesederajatan dalam perbedaan-perbedaan kebudayaan atau latar belakang siswa.

Pendidikan multikultural adalah salah satu pendekatan yang menekankan terhadap pengenalan siswa dan menghargai budaya yang berbeda dari budaya asal mereka. Dalam cakupan yang lebih luas, dalam sistem pendidikan nasional merupakan salah satu solusi bagi keragaman budaya yang dimiliki bangsa Indonesia yang terdiri dari berbagai suku, bahasa dan agama. ${ }^{6}$

4 Joko Tri Prasetya, Imu Budaya Dasar, (Jakarta: PT. Rineka Cipta, 2009), h. 28.

5 Suparlan Parsudi, Multikulturalisme Sebagai Modal Dasar Bagi Aktualisasi Kesejahteraan, (Jakarta: PT. Rineka Cipta, 2009), h. 14.

6 Musa Asy'arie, Pendidikan Multikultural dan Konflik Bangsa, diakses secara online di http://www.kompas.com/kompascetak/0409/03/opini/1246546. 


\section{B. Pendidikan Multikultural Menurut Para Ahli:}

1. Azyumardi Azra, mendefinisikan multikultural sebagai pendidikan tentang keragaman kebudayaan dalam merespons perubahan demografi dan kultur lingkungan masyarakat tertentu atau bahkan dunia secara keseluruhan. ${ }^{7}$

2. Hariansyah, dari sudut pandang psikologis, menjelaskan bahwa pendidikan multikultural memandang manusia memiliki beberapa dimensi yang harus diakomodir dan dikembangkan secara keseluruhan bahwa kemanusiaan manusia pada dasarnya adalah pengakuan akan pluralitas, heterogenitas, dan keberagamaan manusia itu sendiri. Keberagamaan itu bisa berupa ideologi, agama, paradigma, pola pikir, kebutuhan, keinginan, dan tingkat intelektualitas. ${ }^{8}$

Dari penjelasan tentang pendidikan multikultural tersebut terdapat dua sudut pandang, pertama, pengertiannya secara umum, dan kedua, pengertian secara khusus yang lebih menekankan kepada aspek keragaman dan kesederajatan siswa dalam proses pendidikan.

\section{Pendidikan Multikultural di Indonesia}

Pendidikan multikultural menemukan relevansinya untuk konteks Indonesia. Secara horizontal, berbagai kelompok masyarakat yang kini dikategorikan sebagai 'bangsa Indonesia' dapat dipilah-pilah dalam berbagai suku bangsa, kelompok penutur bahasa, golongan penganut ajaran agama yang berbeda satu dengan yang lainnya. Sedangkan secara vertikal, berbagai kelompok masyarakat itu dibeda-bedakan atas mode of production yang bermuara pada perbedaan kelas sosial dan budaya. ${ }^{9}$

Dalam konteks Indonesia, peserta didik di berbagai lembaga pendidikan diasumsikan juga terdiri dari peserta didik yang memiliki beragam latar belakang agama, etnik,

7 Ahmad Gaus, dkk, Cerita Sukses Pendidikan Multikultural di Indonesia, (Jakarta: Center For The Study Of Religion and Culture (CSRC) UIN Syarif Hidayatullah Jakarta, 2008), h. 28.

8 Suwitno \& Fauzan, Sejarah Sosial Pendidikan Islam, (Jakarta: Kencana Persada Media, 2005), h. 26.

9 Mahfud, Pendidikan Multikultural, (Jakarta: Kencana Persada Media, 2005), h. 76.

174| Al Amin: Jurnal Kajian Ilmu dan Budaya Islam, Volume 1, No 2, 2018 
bahasa dan budaya. Asumsi ini dibangun berdasarkan pada data bahwa di Indonesia terdapat 250 kelompok suku, 250 lebih bahasa lokal (lingua franca), 13.000 pulau dan 5 agama resmi. ${ }^{10}$

\section{Penerapan Konsep Pendidikan Multikultural di Lembaga Pendidikan}

Menurut Rodolfo Stavenhagen, ${ }^{11}$ pendidikan multikultural harus didasarkan pada tujuan untuk menciptakan stabilitas dan integrasi nasional. Untuk mewujudkan pendidikan multikultural membutuhkan telaah ulang terhadap berbagai konsep pendidikan yang meliputi tujuan pendidikan, muatan kurikulum, metode pembelajaran dan berbagai konsep tentang lembaga pendidikan formal. Oleh karena itu, terdapat beberapa prinsip pokok yang harus diperhatikan dalam melaksanakan pendidikan multikultural:

\section{Menekankan Kualitas Proses Ketimbang Hasil}

Terkait dengan upaya meningkatkan kualitas proses belajar, salah satu caranya adalah dengan tidak membebankan guru terhadap setoran target materi dalam waktu yang telah ditentukan tetapi juga dengan memberikan kebebasan bagi seorang guru untuk menentukan model pembelajaran di kelas agar guru mengetahui cara mana yang paling efektif dalam proses pembelajaran, sehingga dengan upaya ini, kualitas proses belajar siswa menjadi lebih efektif.

\section{Murid Bukan Sekadar Objek Pendidikan Tetapi Subjek Pendidikan}

Murid bukan hanya sebagai peserta didik tetapi juga sebagai subjek pendidikan dimana murid diberikan kesempatan untuk menyampaikan beberapa keinginan, terkait dengan proses pendidikan yang dijalani, sehingga terjalin hubungan yang baik antara guru dan siswa yang menciptakan pembelajaran yang baik dan menyenangkan.

\section{Menghargai Perbedaan}

10 Tadris, "Islam dan Pendidikan Multikultural", Jurnal Pendidikan Islam, 2009, h. 160.

11 https://en.wikipedia.org/wiki/Rodolfo_Stavenhagen, (Commission on Human Rights Resolution, 2001. 
Menghargai perbedaan adalah salah satu sikap yang harus dikembangkan dalam rangka mewujudkan pendidikan multikultural. Latar belakang sosial ekonomi yang berbeda merupakan aset yang sangat berharga dalam dunia pendidikan, bertujuan agar siswa dapat saling menghargai dan biasa berbeda.

\section{Special Treatment for Special Student}

Sekolah mempunyai kewajiban untuk memberikan penghargaan atas setiap prestasi yang mampu diraih oleh para siswa. Hal ini dimaksudkan untuk mendorong semangat para siswa agar berkembang sesuai dengan potensi yang siswa miliki. Sekolah tidak mempunyai hak untuk memaksa anak berkembang mengikuti programprogram yang tidak dimaui anak, melainkan memberikan pelayanan terhadap potensi-potensi yang mereka miliki. Karena dengan potensi tersebut anak dapat hidup dengan layak pada mendatang.

\section{Menerapkan Kurikulum Pendidikan yang Tepat}

Desain kurikulum yang digunakan dalam kegiatan proses belajar mengajar hendaknya disesuaikan dengan arah pertumbuhan dan perkembangan anak. Salah satu cara yang dapat ditempuh oleh sekolah dalam mendesain kurikulum adalah melibatkan masyarakat sebagai salah satu sumber belajar untuk memberikan berbagai masukan dalam penyusunan kurikulum terutama beberapa kurikulum yang berhubungan dengan muatan lokal sehingga diharapkan dengan kurikulum ini dapat mencapai sasaran dan tujuan yang diinginkan. ${ }^{12}$

\section{E. Nilai-nilai Utama, Penerapan dan Tujuan Pendidikan Islam Multikultural di Indonesia}

Nilai-nilai utama dalam pendidikan Islam multikultural meliputi beberapa aspek yaitu:

1. Tauhīd, yaitu mengesakan Tuhan. Pandangan hidup manusia bertujuan untuk merealisasi konsep keesaan Tuhan dalam hubungan antar sesama manusia. Tuhan merupakan sumber utama bagi umat manusia, karenanya

12 Cendekia, Jurnal Kependudukan dan Kemasyarakatan, "Pendidikan Multikultural dan Implementasinya dalam Pendidikan", 2005, h. 31-33.

176| Al Amin: Jurnal Kajian Ilmu dan Budaya Islam, Volume 1, No 2, 2018 
sesama manusia adalah bersaudara (ukhuwah basyariyah).

2. Ummah, yaitu Hidup bersama. Semua orang memiliki akses yang sama untuk tinggal di jagat raya ini, saling berdampingan, dan mengikat hubungan sosial dalam sebuah kelompok, komunitas, masyarakat, atau bangsa.

3. Rahmah, yaitu Kasih sayang, yakni perwujudan sifat-sifat tuhan yang maha pengasih lagi maha penyayang kepada manusia yang di ciptakan oleh tuhan untuk berinteraksi dan berkomunikasi satu sama lain atas dasar semangat saling mengasihi dan peduli.

4. Musāwah, takwa (egalitarianisme) yaitu bahwa semua manusia adalah bersaudara dan mendapat perlakuan yang sama di hadapan Allah Swt. Meskipun berbeda jenis kelamin, gender, ras, warna kulit dan agama. ${ }^{13}$

Berikut ini beberapa penerapan nilai multikultural dalam Islam yaitu:

a. Ta'āruf (saling mengenal dan berbuat baik) yaitu kesadaran dan keinginan untuk tinggal bersama, berdampingan dengan yang lain yang berbeda budaya, etnis dan agama, agar dicapai wawasan etnis yang luas, saling bekerja sama, saling memberi dan menerima, serta siap berkorban.

b. Tafāhum (saling memahami) yaitu kesadaran bahwa nilainilai mereka adalah berbeda, dan bahwa kita saling melengkapi satu sama lain dan memberi kontribusi dan hubungan yang dinamis terhadap pihak lain.

c. Fastabiq al-khairāt (berlomba-lomba dalam kebaikan) yaitu persamaan dan perbedaan dapat mendukung terjalinnya komunikasi dan kompetisi antar individu dan kelompok untuk memperoleh harga diri dan mutu pada semua aspek kehidupan sosial.

d. Amānah, saling mempercayai: untuk menjaga sikap mempercayai dalam hubungan antarsesama manusia.

e. Husnuzan, agar memiliki pikiran positif berarti haruslah awas dalam menghakimi seseorang dalam suatu permasalahan.

f. Tasāmuh, toleransi Artinya menerima kebebasan beragam dan berekspresi serta menghormati keragaman dalam agama, budaya, dan etnis.

13 Tadris, "Islam dan Pendidikan Multikultural", h. 24. 
g. 'Afw, yaitu memberikan maaf yang berarti melupakan semua bentuk penyiksaan, kejahatan, dan perbuatan salah. Pemberi ampunan berarti dua hal, yakni memaafkan pada saat kita punya kekuatan untuk membalas dendam, dan meminta maaf di saat kita tak punya untuk membalas.

h. Takrim, saling menghormati artinya saling menghormati merupakan nilai-nilai universal yang ada di dalam semua agama dan budaya dimana kita dapat mempersiapkan diri kita untuk mendengarkan pendapat dan perspektif yang berbeda, juga untuk menghormati nama baik (kemuliaan) dari berbagai individu maupun kelompok.

i. Sulh, perdamaian atau rekonsiliasi yakni jalan yang terpilih untuk mengumpulkan konsep kebenaran, ampunan dan keadilan setelah kekerasan terjadi.

j. Ișlāh atau resolusi konflik yaitu penekanan pada kekuatan hubungan antara dimensi psikologis dan kehidupan politik masyarakat melalui kesaksian bahwa penderitaan individu atau kelompok tentulah akan tumbuh dengan cepat bilamana kita tidak memahami, mengampuni, dan menyelesaikan konflik. ${ }^{14}$

Berikut tujuan mempelajari nilai-nilai utama dalam pendidikan Islam multikultural:

a. Silāh, yakni membangun perdamaian, menjaga perdamaian dan membuat perdamaian.

b. Layyin, yakni lemah lembut atau budaya anti kekerasan. Yakni perilaku, perkataan, sikap, serta berbagai struktur dan sistem yang memelihara dan menjaga fisik, mental sosial, dan menjadi aman dan damai.

c. 'Adl atau keadilan, yaitu membuat keseimbangan yang membuat ras peduli, saling berbagi, serta sikap moderat dalam merespons perbedaan, jujur dan terbuka dalam segala sudut pandang atau perbuatan. ${ }^{15}$

\section{F. Rivalitas Pendidikan Agama Islam dalam Pendidikan Multikultural}

Pada umumnya, pendidikan agama diberikan di sekolah-sekolah tidak menghidupkan pendidikan

14 Tadris, "Islam dan Pendidikan Multikultural", h. 25.

15 Abd. Rahcman Assegaf, Filasafat Pendidikan Islam, (Jakarta: PT. Rajagrafindo Persada, 2011), h. 313-314.

178| Al Amin: Jurnal Kajian Ilmu dan Budaya Islam, Volume 1, No 2, 2018 
multikultural yang baik, bahkan cenderung berlawanan. Akibatnya konflik sosial sering kali diperkeras oleh adanya legitimasi keagamaan yang diajarkan dalam pendidikan agama di sekolah-sekolah daerah yang rawan konflik. Ini membuat konflik yang mempunyai akar dalam keyakinan keagamaan yang fundamental sehinga konflik sosial dan kekerasan semakin sulit diatasi, karena dipahami sebagai panggilan agamanya. ${ }^{16}$

Sebenarnya akar timbulnya berbagai konflik sosial yang membuahkan anarki yang berkepanjangan sering kali tidak ada hubungannya dengan agama, tetapi dalam kenyataannya agama selalu menjadi bagian yang tak terpisahkan dari berbagai konflik sosial tersebut.

Potensi konflik dan desintegrasi tersebut disebabkan karena agama dalam manifestasinya bersifat ambivalen terhadap persatuan dan kesatuan. Artinya, meskipun agama memiliki kekuatan mempersatu, agama juga mempunyai kekuatan pemecah belah. Ada beberapa alasan menurut Din Syamsudin ${ }^{17}$ mengapa agama memiliki ambivalensi seperti itu salah satu nya adalah agama memiliki kecenderungan absolutistik, yaitu kecenderungan untuk memutlakkan keyakinan keagamaannya sebagai kebenaran tunggal. Akibatnya muncul rejeksionis, yaitu penolakan terhadap kebenaran agama lain. ${ }^{18}$ Yang dianggap berbeda dari dan berlawanan dengan yang lain. Akar konflik keagamaan seperti ini kata Athur D'Adamo karena para pemeluk agama mengambil sikap untuk memandang agama dari sudut pandang agamanya sendiri. Sehingga yang lebih mencuat ke permukaan bukanya esensi kebenaran yang hendak ditawarkan oleh agama, melainkan semangat untuk menegasikan yang lain.

Disebabkan oleh truth claim itulah, maka setiap agama menyatakan ajarannya merupakan totalitas sistem makna yang berlaku bagi seluruh kehidupan, baik individual

16 Musa Asy'arie, Pendidikan Multikultural dan Konflik Bangsa, diakses secara online di http://www.kompas.com/kompascetak/0409/03/opini/1246546.

17 Nizar Samsul, Sejarah dan Pergolakan Pemikiran Pendidikan Islam, (Ciputat: Quntum Teaching, 2005), h. 34.

18 Budy Munawarah Racman, Pengantar dalam Komarudin Hidayat dan Muhammad Wahyuni Nafis, Agama Masa Depan dalam Perspektif Filsafat Perenial, (Jakarta: Yayasan Paramadina, 1995), h. 27. 
maupun sosial sehingga secara kodrati cenderung menegaskan klaim kebenaran teologis yang dimilikinya. Namun ketika agama-agama itu hadir secara historis, ia berhadapan dengan pluralisme keagamaan sebagai pluralisme keagamaan sebagai realitas sosial yang hidup di tengah masyarakat, maka akan berimplikasi pada perilaku sosial. Dalam kontes inilah pandangan inklusif sangat diperlukan untuk menerima kenyataan hidup pluralisme sebagai syarat mutlak bagi penganut agama apapun.

Kenyataan menunjukkan bahwa pendidikan agama masih diajarkan dengan cara menafikan hak hidup agama yang lainnya, seakan-akan hanya agamanya sendirilah yang benar dan mempunyai hak hidup, sementara agama yang lain salah, tersesat dan terancam hak hidupnya, baik di kalangan mayoritas maupun yang minoritas. Semangat pendidikan keagamaan yang sempit ini sudah barang tentu berlawanan secara fundamental dengan semangat pendidikan multikultural, dan akan memperlemah persatuan bangsa. Karena itu, pendidikan agama Islam harus direvitalisasi dan direaktualisasi secara kreatif dan berwawasan multikultural sehingga tidak kehilangan jiwa dan semangatnya.

Karena pada dasarnya masyarakat kultural tidak hanya ciri khas masyarakat Indonesia. Dalam pandangan paling dini historisitas keberagaman Islam era kenabian Muhammad Saw, masyarakat yang pluralistik secara religius telah terbentuk bahkan telah menjadi kesadaran umum pada saat itu. Kondisi demikian merupakan kewajaran lantaran secara kronologis agama Islam memang muncul setelah beberapa agama yang telah ada sebelumnya.

Bukti empiris sejarah peradaban Islam di masa lalu, menunjukkan Islam tampil secara inklusif dan sangat menghargai non-muslim. Sikap inklusif ini ada karena alQur'an mengajarkan paham religius plurality. Bagi orang Islam, dianut suatu keyakinan sampai hari ini di dunia pun akan terdapat keragaman agama. Meskipun ada klaim bahwa kebenaran agama ada pada Islam. Namun dalam alQur`an juga disebutkan adanya hak orang lain untuk beragama. Dan agama tidak bisa dipaksakan oleh orang lain. Sikap inilah yang menjadi prinsip kejayaan Islam sekaligus mendasari kebijakan politik kebebasan beragama.

Ajaran tauhid dalam Islam mengandung pengertian adanya suatu orde yang satu sekaligus menyeluruh. Dengan 
kata lain terdapat hukum abadi yang universal. Menurut Joko Tri Prasetyo, ${ }^{19}$ hukum yang abadi dan berlaku universal adalah berawal dari suatu keyakinan bahwa manusia adalah satu dan tercipta karena kehendak yang satu, yaitu Tuhan pencipta alam. Kesadaran yang demikian hanya tumbuh pada manusia yang menyadari prinsip-prinsip moral yang dapat mempersatukan perasaan dan merupakan dasar kebajikan.

Seorang agamawan memang dituntut untuk mempunyai sikap yang lebih realistis ketika berhadapan dengan realitas empiris kehidupan yang beragama terutama dalam memosisikan agama. Seperti yang dikemukakan oleh Hans Kung bahwa kedudukan harus dilihat dari dua arah. Pertama, dari luar yakni diakui oleh bermacam-macam agama yang benar. Inilah dimensi relatif suatu agama. Agama-agama mempunyai satu tujuan yaitu keselamatan (dengan konsep yang berbeda-beda) dengan jalan yang berbeda-beda, sehingga lewat perbedaan ini, agama-agama bisa memperkaya satu sama lain. Kedua, dari dalam, diakui adanya suatu agama yang benar, inilah dimensi mutlak suatu agama. Pendidikan ini tidak harus menolak kebenaran agama-agama lain walaupun pada tingkat-tingkat tertentu, sejauh tidak bertentangan dengan pesan agama yang dianut.

Melalui pemahaman mendalam terhadap nilai-nilai etik yang fundamental yang dimiliki oleh peserta didik dapat menjadi penghubung pengikut agama satu dengan agama lainnya. Konflik sosial yang mewarnai pasang surutnya persatuan Indonesia harus menjadi perhatian dan perlu diawasi oleh kemampuan manajemen politik bangsa agar tidak berkembang menjadi kekuatan yang memecah belah persatuan Indonesia. Salah satu cara strategis adalah pendidikan multikultural yang dilakukan secara aktual, cerdas, dan jujur.

Pendidikan apapun bentuknya, tidak boleh kehilangan dimensi multikulturalnya, termasuk di dalamnya pendidikan keagamaan dan dan keilmuan, karena realitas dalam kehidupan pada hakikatnya multidimensional. Karena itu, untuk mengatasi problem kemanusiaan yang ada, tidak bisa lain kecuali dengan menggunakan pendekatan yang

19 Prasetia Joko Tri, Ilmu Budaya Dasar, (Jakarta: PT. Rineka Citra, 2009), h. 19. 
multidimensional yang di dalamnya adalah pendidikan multikultural.

\section{G. Konsep Dasar Pendidikan Islam Multikultural Zaman Al- Ma'mun}

Bila ditelusuri pada institusi pendidikan Islam ternyata ditemukan konsep dasar pendidikan multikultural yaitu ketika al-Ma'mun menjadi khalifah (813-833 M) dari Bani Abbas di Bait al-Hikmah yaitu institusi Pendidikan tinggi Islam pertama yang dibangun pada tahun $830 \mathrm{M}$ oleh khalifah al-Ma'mun. ${ }^{20}$

Berikut ini dapat digambarkan dengan jelas adanya konsep dasar multikultural pada institusi Bait al-Hikmah:

1. Nilai-nilai kebebasan berekspresi, keterbukaan, toleransi, dan kesetaraan dapat dijumpai pada proses pengumpulan manuskrip-manuskrip dan penerjemah buku-buku sains dari yunani untuk melengkapi institusi Pendidikan Bait al-Hikmah yang didirikan al-Ma'mun. Al-Ma'mun telah memberikan kebebasan berekspresi, keterbukaan dan kesetaraan kepada sarjana muslim dan non-muslim serta memberikan penghargaan yang sama kepada kedua kelompok sarjana tersebut dalam membentuk membayar mahal kepada para penerjemah setara bobot emas.

2. Perbedaan etnik kultural dan agama bukan halangan melakukan penerjemahan. Kepada penerjemah yang memiliki etnik kultural dan agama, diantaranya Abu Sahl Fazhl ibn Nawbakht (Persia), Yuhana ibn Masuya (Syria), Qutha ibn Luqa (Kristen Yocabite), Abu Bisr Matta ibn Yunus (Kristen Nestorian).

Adapun konsep dasar multikulturalisme yang terkandung selain pada Bait al-Hikmah, seperti Institusi Pendidikan Islam maktab/kuttāb, masjid, ribāt, halaqah yaitu:

a. Nilai-nilai kebebasan dan kesetaraan tergambar dalam proses belajar mengajar di Institusi Pendidikan Islam yaitu di masjid. Murid mempunyai kebebasan dalam memilih materi pelajaran dan gurunya. Masjid-masjid memberikan kebebasan kepada murid untuk

20 Asar, Pendidikan Tinggi Islam, (Jakarta: Bulan Bintang, 1994), h. 109.

182| Al Amin: Jurnal Kajian Ilmu dan Budaya Islam, Volume 1, No 2, 2018 
mengadakan halaqah-halaqah. Murid-murid bebas memilih guru, memilih materi pelajaran dan tempat belajar yang mereka sukai dan yang mereka anggap paling baik.

b. Nilai-nilai keadilan, kemiskinan dan keterbelakangan kelompok minoritas tampak pada proses rekrutmen murid. Murid-murid yang tidak mampu murid-murid yang yatim diberikan kesempatan yang sama untuk menuntut ilmu. Murid-murid yang miskin juga mendapat fasilitas yang luar biasa dari lembaga wakaf. Ini artinya telah melaksanakan konsep demokrasi tanpa adanya diskriminasi.

c. Nilai-nilai keadilan dan hubungan yang harmonis tergambar dalam hubungan guru dan murid dalam proses belajar mengajar. Guru memberikan perlakuan yang sama kepada semua muridnya dan memberikan perhatian yang penuh kepada mereka. Situasi ini berdampak kepada tingginya minat murid yang untuk belajar dan melanjutkan pendidikan ke tingkat yang lebih tinggi.

Berkembangnya ilmu pengetahuan dan peradaban yang menjadi tonggak puncak peradaban Islam zaman keemasan dalam Islam disebabkan karena institusi pendidikan Islam yang ada telah menerapkan konsep pendidikan berbasis multikultural. Nilai-nilai multikultural yang aktual dikembangkan saat itu adalah toleransi, keterbukaan, kesederajatan, kebebasan, keadilan, kemiskinan, keragaman dan demokrasi. Pesatnya peradaban dan perkembangan ilmu juga didukung oleh tokoh-tokoh pendidik yang memiliki visi dan misi yang berbasis multikultural, seperti:

1. Khalifah al-Ma'mun (813-833 M)

Nama asli al-Ma'mun adalah Abdul Abbas Abdullah alMa'mun (783-833 M). Ia seorang khalifah Abbasiyah, putra dari Harun al-Rasyid. Ia dikenal sebagai tokoh pendidikan multikultural karena ia sangat toleran terhadap masyarakat yang berbeda agama yaitu Kristen, serta ia lebih familiar terhadap peradaban yang berbedabeda seperti Rusia, Pagan dan lain-lain.

2. Muhammad ibn Musa al-Hawarizmi (780-850 M) 
Beliau ahli tentang aljabar dan astronomi, direktur perpustakaan Bait al-Hikmah atau pusat studi dan riset astronomi dan matematika. Beliau seorang pendidik multikultural karena ikut menciptakan suasana bebas, terbuka, toleran, dan sederajat dalam mengelola Bait alHikmah dan upaya menerjemahkan buku-buku warisan Hellenisme dari Yunani kedalam bahasa Arab.

\section{3. al-Kindi (809-866 M)}

Ia adalah ilmuwan dan filsuf muslim pertama yang dikenal sebagai pendidik multikultural karena ia dikenal adalah sosok yang humanis dan orang yang pertama kali mengajak kaum muslimin untuk hidup saling memahami dan menyelaraskan pemikiran-pemikiran yang berbedabeda. ${ }^{21}$

\section{H. Kesimpulan}

Multikulturalisme secara sederhana dapat dipahami secara pengakuan, bahwa sebuah negara atau masyarakat adalah beragam dan majemuk. Sebaliknya negara tidak hanya mengembangkan kebudayaan nasional tunggal. Satu hal yang penting dicatat, keragaman itu hendaklah tidak dinterpretasikan secara tunggal. lebih jauh, komitmen untuk mengakui keragaman sebagai salah satu ciri dan karakter utama masyarakat dan negara bangsa (nation state) tidaklah berarti relativisme kultural, ketercerabutan destruksi sosial atau konflik berkepanjangan.

Secara sederhana pendidikan adalah usaha untuk menumbuhkan dan mengembangkan potensi-potensi bawaan baik jasmani maupun rohani sesuai dengan nilainilai yang ada di dalam masyarakat dan kebudayaan. Dalam pengertian yang luas pendidikan sama dengan hidup, dalam arti, segala situasi dalam hidup yang mempengaruhi pertumbuhan seseorang. Pendidikan juga bisa diartikan sebagai keseluruhan pengalaman belajar setiap orang sepanjang hidupnya. Sehingga pendidikan tidak berlangsung dalam usia tertentu tetapi sepanjang hidup manusia.

Pendidikan multikultural diharapkan dapat menyelesaikan persoalan konflik yang terjadi di masyarakat, atau paling tidak mampu memberikan penyadaran kepada

21 Suwito, Sejarah Sosial Pendidikan Islam, (Jakarta: Prenada Media, 2005), h. 30-33.

184| Al Amin: Jurnal Kajian Ilmu dan Budaya Islam, Volume 1, No 2, 2018 
Saihu

masyarakat bahwa konflik bukanlah suatu hal yang baik untuk dibudayakan. Pendidikan harus mampu memberikan tawaran-tawaran yang mencerdaskan, antara lain dengan cara mendesain materi, metode hingga kurikulum yang mampu menyadarkan masyarakat akan pentingnya sikap toleran menghormati perbedaan suku, agama, ras, etnis dan budaya masyarakat Indonesia yang multikultural. 


\section{DAFTAR PUSTAKA}

Abd. Rahcman Assegaf, Filasafat Pendidikan Islam Jakarta: PT. Rajagrafindo Persada, 2011.

Ahmad Gaus, dkk, Cerita Sukses Pendidikan Multikultural di Indonesia, Jakarta: Center For The Study Of Religion and Culture (CSRC) UIN Syarif Hidayatullah Jakarta, 2008.

Asar, Pendidikan Tinggi Islam, Jakarta: Bulan Bintang, 1994.

Azyurmadi Azra, Pendidikan Islam, Tradisi dan Modernisasi Menuju Milenium Baru, Jakarta: Logos 1990.

Budy Munawarah Racman, Pengantar dalam Komarudin Hidayat dan Muhammad Wahyuni Nafis, Agama Masa Depan dalam Perspektif Filsafat Perenial, Jakarta: Yayasan Paramadina, 1995.

Cendekia, Jurnal Kependudukan dan Kemasyarakatan, Pendidikan Multikultural dan Implementasinya dalam Pendidikan, 2005.

Herry Sucipto, Lili Hermawan, Pendidikan Multikultural untuk Kemajuan Bangsa, dalam Nadjamuddin Ramly, Membangun Pendidikan Yang Memberdayakan dan Mencerahkan, Jakarta: Grafindo, 2005.

http://www.kompas.com/kompascetak/0409/03/opini/ 124 6546.

http:/ /www.kompasiana.com/satriwan/pendidikankarakter-dalam-bingkai-multikulturalisme.

https://en.wikipedia.org/wiki/Rodolfo_Stavenhagen, Commission on Human Rights Resolution, 2001.

Joko Tri Prasetya, Ilmu Budaya Dasar, Jakarta: PT. Rineka Cipta, 2009.

Mahfud, Pendidikan Multikultural, Jakarta: Kencana Persada Media, 2005.

Nizar Samsul, Sejarah dan Pergolakan Pemikiran Pendidikan Islam, Ciputat: Quntum Teaching, 2005.

Prasetia Joko Tri, Ilmu Budaya Dasar, Jakarta: PT. Rineka Citra, 2009. 
Saihu

Suparlan Parsudi, Multikulturalisme Sebagai Modal Dasar Bagi Aktualisasi Kesejahteraan, Jakarta: PT. Rineka Cipta, 2009.

Suwitno \& Fauzan, Sejarah Sosial Pendidikan Islam, Jakarta: Kencana Persada Media, 2005.

Suwito, Sejarah Sosial Pendidikan Islam, Jakarta: Prenada Media, 2005.

Tadris, Islam dan Pendidikan Multikultural, Jurnal Pendidikan Islam, 2009. 